\title{
HEGEMONI DAN NEGOSIASI DALAM GAYA BERBUSANA
}

\author{
Wury Dwiwardani ${ }^{1 *}$, Wahyu Handayani Setyaningsih ${ }^{1}$ \\ ${ }^{1}$ Universitas Gadjah Mada, Indonesia \\ *e-mail: wury dwiwardani@ugm.ac.id
}

\begin{abstract}
Abstrak
Tulisan ini berangkat dari ketertarikan pada fenomena fashion statement dari para pejabat publik akhir-akhir ini yang mendapat perhatian dari masyarakat luas. Saat ini, seorang pejabat publik tidak hanya akan mendapatkan perhatian dari khalayak luas karena official atau political statement yang disampaikannya, namun juga karena fashion statement yang ditampilkannya. Fashion statement tersebut memunculkan berbagai pendapat yang merepresentasikan nilai-nilai hegemonik terkait kode-kode fashion yang berlaku, sekaligus juga upaya melakukan negosiasi dan transformasi atasnya. Penelitian ini bertujuan untuk menjelaskan bagaimana hegemoni bekerja mengontrol persepsi masyarakat dalam memahami realitas, dan bagaimana negosiasi dan transformasi terjadi dalam kode-kode fashion. Analisis dilakukan dengan mencermati artikel dan komentar-komentar warganet di media-media daring untuk melihat makna yang tersirat. Hasil dari penelitian menunjukkan bahwa terlihat adanya upaya untuk melakukan negosiasi dan transformasi pada kode-kode fashion. Fashion dan gagasan-gagasan yang disematkan padanya memunculkan kebutuhan mengkonsumsi pakaian serta assories penyertanya, dan membuka pasar yang tidak pernah mati bagi bisnis dan industri fashion. Pada akhirnya hegemoni budaya pada produk fashion bekerja untuk penguasa yang sesungguhnya, yaitu mereka para pemilik modal.
\end{abstract}

Kata kunci: Kode-Kode Fashion; Hegemoni Budaya; Negosiasi

\begin{abstract}
This research's background is the phenomenon of fashion statements from public officials who recently received public attention. Today's public officials will get public attention because of their official or political statements and their fashion statements. Their fashion statements have raised various opinions from the public, reflecting hegemonic ideas from the fashion codes and efforts to negotiate and transform them. This study aims to explain how hegemony works in controlling people's perceptions in understanding reality and how negotiation and transformation occur in fashion rules. The analysis is carried out by examining public comments on online media to see the implied meaning. The result shows that there are attempts to negotiate and transform the fashion codes. The fashion codes and hegemonic ideas embedded in them have increased the need to consume clothes and accessories and open a market opportunity that never dies for the fashion industry. Finally, the cultural hegemony of fashion products works for the fundamental authorities, namely the owners of the capital.
\end{abstract}


Wury Dwiwardani, Wahyu Handayani Setyaningsih | Hegemoni dan Negosiasi dalam Gaya Berbusana

Keywords: Fashion Codes; Cultural Hegemony; Negotiation

This is an open access article under the CC BY-SA license.

Copyright (C 2021 by Author. Published by Universitas Pendidikan Ganesha.

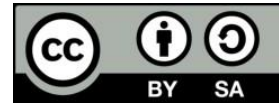

\section{PENDAHULUAN}

Beberapa hari pasca peristiwa ambruknya bangunan Sekolah Dasar Gentong (5/11/2019) di Pasuruan yang menimbulkan keprihatinan masyarakat luas, Nadiem Makarim, yang belum lama sebelumnya dilantik sebagai Menteri Pendidikan dan Kebudayaan datang berkunjung untuk melihat langsung dan mendapatkan berbagai informasi terkait permasalahan tersebut. Kunjungan tersebut tentu bukan hal yang luar biasa. Sambutan dari Dinas Pendidikan setempat pada saat kedatangannya pun merupakan kejadian yang lazim. Sambutan tidak biasa justru datang dari warganet. Sambutan tersebut bukan ditujukan untuk langkah Nadiem, bukan pula untuk buah pikiran yang dilontarkannya saat itu, tetapi pada kemeja hitam dan celana jeans yang dikenakan, pada tas ransel yang disandangnya. Khalayak dunia maya justru sibuk membahas gaya berpakaian menteri pendidikan yang mereka sebut sebagai menteri dari generasi millenial itu. Sebagian warganet memberikan pujian, namun tidak sedikit pula yang mengkritik pilihan busana tersebut.

Kejadian tersebut di atas mengingatkan pada kejadian lain yang serupa beberapa tahun sebelumnya. Kala itu banyak masyarakat memberi perhatian pada pilihan busana yang dikenakan oleh Presiden Joko Widodo saat la berbicara di sebuah konferensi pers terkait peristiwa demonstrasi besar yang terjadi pada tanggal 4 November 2016. Konferensi pers ini mendapatkan perhatian dari berbagai kalangan karena terkait dengan demonstrasi yang terjadi sebelumnya, sebagai imbas dari sebuah peristiwa yang banyak menyita perhatian masyarakat. Namun,ternyata tidak hanya isi dari penjelasan yang disampaikan dalam konfrensi pers tersebut, penampilan Presiden, yang biasa disapa dengan Presiden Jokowi ini, malam itu juga mendapat perhatian yang cukup besar dari masyarakat. Malam itu, Presiden tidak mengenakan pakaian formal ala kepresidenan, dan memilih untuk mengenakan jaket yang sering disebut dengan model jaket bomber, yang dipadupadankan dengan celana panjang hitam. Jaket bomber yang dikenakan Presiden Joko Widodo saat itu berwarna hijau army/ hijau lumut dengan variasi berwarna hitam di bagian kerah leher, dan zipper di bagian depan dan lengan. Busana tersebut menjadi pembicaraan ramai di berbagai media daring dan bahkan kemudian diliput pula oleh media asing, yang salah satunya adalah Reuters, dalam artikelnya yang bertajuk "Indonesian President's Call for Calm Makes Fashion Statement." (Jensen \& Nangoy, 2019).

Fenomena-fenomena tersebut di atas menunjukkan bahwa pada selembar kain yang kelihatannya sepele itu terkandung 'nilai' yang bagi masyarakat luas ternyata sama sekali tidak sepele. Bagaimana pakaian yang lazim, yang

Jurnal IImu Sosial dan Humaniora | 100 
boleh dan tidak boleh, yang layak dan tidak layak, telah disepakati secara luas, dan menjadi sebuah common sense. Peristiwa yang memperlihatkan ketidaksesuaian dengan kelaziman yang selama ini diterapkan menimbulkan perdebatan pro dan kontra.

Dalam tulisan ini akan dipaparkan bagaimana hegemoni terkait kode-kode fashion bekerja di masyarakat dalam peristiwa-peristiwa tersebut di atas. Sekaligus juga akan dilihat bagaimana upaya negosiasi dan sikap kompromis yang berkaitan dengan kode-kode fashion tersebut tertangkap dalam pilihan-pilihan berbusana dan komentarkomentar warganet di berbagai media daring yang menanggapinya. Fashion, sebagaimana produk-produk budaya popular yang lain menjadi sebuah arena kontestasi untuk merebut, mempertahankan dominasi, dan mengupayakan resistensi serta negosiasi

\section{METODE}

Penelitian dilakukan menggunakan metode kualitatif dengan. data-data penelitian yang diperoleh dari berita-berita media daring terkait pilihan busana pejabat tinggi negara dalam beberapa peristiwa, dan komentarkomentar masyarakat pembaca dalam salah satu berita media daring. Komentar-komentar pembaca diambil dari artikel dari detikNews yang berjudul "Busana 'Santai' Nadiem di Pelantikan Rektor Dikritk, Ini Kata Kemendikbud" (Rizqo, 2019) yang diunggah pada tanggal 06 Des 2019. Pilihan busana yang akan dibahas dalam tulisan ini adalah pilihan busana dari Presiden Joko Widodo dan Menteri Pendidikan dan Kebudayaan Nadiem Makariem, yang terutama akan difokuskan pada tiga peristiwa yaitu peristiwa pelantikan Rektor Universitas Indonesia pada tanggal 4 Desember 2019, konferensi pers Presiden Joko Widodo pada tanggal 4 November 2016, dan pilihan busana yang dikenakan oleh pasangan calon presiden dan calon wakil presiden Joko Widodo dan Ma'ruf Amin dalam foto di kertas suara pemilu presiden dan wakil presiden tahun 2019.

Data-data yang didapatkan dari berita-berita media daring dianalisis dalam sudut pandang konsep hegemoni untuk melihat bagaimana hegemoni bekerja di masyarakat dalam melihat kenyataan, serta upaya-upaya negosiasi dan kompromi-kompromi yang terjadi. Dalam pandangan konsep hegemoni, budaya yang tersebar merata di dalam masyarakat pada waktu tertentu dapat diinterpretasikan sebagai suatu hasil atau perwujudan hegemoni, perwujudan dari penerimaan 'konsensual' oleh kelompok-kelompok gagasan subordinat, tentang nilai-nilai, kepemimpinan kelompok dominan (Strinati \& Muchid, 2010). Dominasi tidak hanya dipraktikkan dengan cara kekerasan, tetapi juga melalui kepemimpinan moral dan intelektual (Gramsi dalam Walton, 2008). Hegemoni, sebagai sarana kultural maupun ideologis, tempat kelompokkelompok yang dominan di masyarakat melestarikan dominasinya, berusaha mengamankan "persetujuan spontan" kelompok-kelompok subordinat, termasuk kelas pekerja, melalui penciptaan negosiasi konsensus politik maupun ideologis yang menyusup ke dalam kelompok-kelompok dominan maupun yang didominasi (Strinati \& Muchid, 2010).

Jurnal IImu Sosial dan Humaniora | 101 


\section{HASIL DAN PEMBAHASAN}

\section{Busana, Identitas, dan Citra Diri}

Sesungguhnya, tidak hanya di masa kini, sejak dahulu masyarakat telah memberi makna lain bagi pakaian, yang tidak sekedar sebagai pelindung tubuh. Fashion menawarkan model-model dan bahan untuk membangun identitas (Kellner \& Rambatan, 2010). Sejak zaman awal pun manusia mengenakan pakaian bukan hanya untuk perlindungan diri, tetapi juga demi identifikasi dan jati diri (Danesi, 2004).

Pada masyarakat tradisional yang memiliki peran sosial dan kodekode aturan yang relatif baku, pakaian dan penampilan sesorang secara langsung menunjukkan kelas sosial, profesi, dan status mereka (Kellner \& Rambatan, 2010). Pada Abad Pertengahan, di Eropa Barat, terdapat aturan-aturan tertulis yang mendikte apa yang boleh atau tidak boleh dikenakan oleh orang dari kelas yang berbeda karena identitas sangat dibatasi (Kellner \& Rambatan, 2010). Revolusi Industri kemudian menjadikan fashion diperuntukkan bagi masyarakat luas, tidak hanya menjadi previlese kaum bangsawan (Danesi, 2004).

Pada awal abad 20, fashion modern merasionalisasi pakaian dan kosmetik, dan pasar massal telah membuat perubahan dalam fashion, sehingga dapat dikonsumsi massal. Modernitas menawarkan kemungkinankemungkinan baru untuk membangun identitas personal, dan memberi kesempatan individu untuk membangun identitas pribadi, dalam batasan-batasan tertentu (Kellner \& Rambatan, 2010). Meskipun terdapat kemungkinankemungkinan baru, namun kode fashion tetap relatif baku di beberapa kelas dan wilayah, karena dalam masyarakat modern fashion dibatasi oleh kode gender, realitas ekonomi, dan kekuatan konformitas sosial yang terus mendikte apa yang boleh dan tidak boleh dipakai serta apa yang mungkin dan tidak mungkin (Kellner \& Rambatan, 2010). Orang tua, guru, dan penentu selera yang baik turut mengontrol kode-kode fashion dan indentitas dengan mendikte fashion yang patut dan tidak patut (Kellner \& Rambatan, 2010).

Masyarakat mengenal istilah fashion untuk menyebut aturan berbusana, gaya, atau kebiasaan yang lazim dalam berpakaian. "Fashion adalah semacam kode berpakaian makro yang menetapkan standard gaya menurut usia, gender, kelas sosial, dan seterusnya." (Danesi, 2004, p. 187). Fashion hingga kini masih menjadi komponen penting yang dianggap mencerminkan sikap, identitas, dan citra diri. Seperti yang terjadi di masa sebelumnya, kode-kode fashion yang merupakan hegemoni secara kultural ditanamkan melalui institusi-institusi masyarakat, seperti keluarga, pendidikan, agama, media massa, budaya popular, orang-orang yang bergerak di dunia fashion, instansi pemerintah dan swasta, dan lain-lain, termasuk yang akhir-akhir ini muncul bersama dengan berkembangnya media sosial daring yaitu para pesohor dunia maya yang sering disebut sebagai fashion influencer. Mereka turut berperan sebagai apparatus yang menginternalisasi hegemoni kode-kode busana dan mempertahankan hegemoni tersebut, sehingga masyarakat akan mematuhinya secara sukarela sebagai

Jurnal IImu Sosial dan Humaniora | 102 
sesuatu yang sudah sewajarnya dilakukan.

Masyarakat pada umumnya telah terinternalisasi dengan gagasangagasan hegemonik kode-kode busana, bahwa terdapat busana yang tepat untuk masing-masing situasi. Busana siang berbeda dengan gaun malam, pakaian kerja tidak sama dengan pakaian pesta, berdandan untuk makan malam di restoran mewah berbeda dari saat akan makan di warung di pingir jalan. Termasuk, dalam kasus Nadiem Makarim, busana 'formal' yang tepat bagi seorang menteri untuk melakukan kunjungan dan acara dinas dianggap seharusnya berbeda dengan busana kasual yang dapat dikenakannya saat bekerja di perusahaan yang dikelolanya sebelumnya. Gagasan-gagasan hegemonik ini yang kemudian membuat pilihan busana Menteri Pendidikan dan Kebudayaan ini menjadi sorotan dan perdebatan.

\section{Hegemoni dan Negosiasi pada Kode- Kode Fashion yang Dominan}

Hegemoni berperan untuk menyemen, mengikat kelas-kelas yang sebenarnya bersifat antagonistik menjadi satu kesatuan yang seakan organik: rukun dan harmonis (Faruk, 2017). Gramsci mengaitkan hegemoni dengan wilayah-wilayah common sense yang biasanya dianggap lugu dan spontan, sesuatu yang dianggap alamiah dan wajar (Faruk, 2017, p. 142). Common sense tersebut terbentuk sebagai hasil proses konfilk dan negosiasi, hingga akhirnya dimenangkan oleh gagasangagasan yang kemudian diterima dan dijalankan sebagai common sense. Hegemoni secara kultural maupun ideologis beroperasi dan dilestarikan pengaruhnya melalui institusi-institusi masyarakat, yang meliputi pendidikan, keluarga, gereja, media massa, budaya populer dan sebagainya (Strinati \& Muchid, 2010).

Manifestasi ideologi hegemonik berlangsung melalui pengaruh budaya yang disebarkan secara sadar dan dapat meresap serta berperan dalam menafsirkan pengalaman tentang kenyataan. Proses penafsiran itu memang berlangsung secara tersembunyi (tersamar), tetapi terjadi secara terus menerus (Althusser dalam Ibrahim et al., 1997). Ideologi hegemonik tentang kode-kode fashion yang mengontrol persepsi masyarakat tentang keharusan berbusana sesuai dengan waktu, tempat, dan acara yang dihadiri telah meresap dan berperan dalam menafsirkan berbagai pengalaman dalam kehidupan.

Pada berbagai pendapat masyarakat terkait pilihan busana Nadiem Makarim, terlihat bahwa hegemoni tentang kode-kode fashion telah menginternalisasi masyarakat pada umumnya. Awal mula pembahasan viral tentang pilihan pakaian Nadiem pada saat kunjungan kerjanya ke Sekolah Dasar Gentong di Pasuruan adalah video yang diunggah oleh akun Instagram dari m. bahrunnajach, dengan komentar penulisnya sebagai berikut.

"Heboh. gaya berpakaian Mas Mendikbud Nadiem Makarim saat kunjungan kerja ke Jawa Timur. Menteri milenial memang beda. Perpaduan kemeja, jeans dan ransel. Simpel ngga kayak pejabat." (m. bahrunnajach)

Jurnal IImu Sosial dan Humaniora | 103 


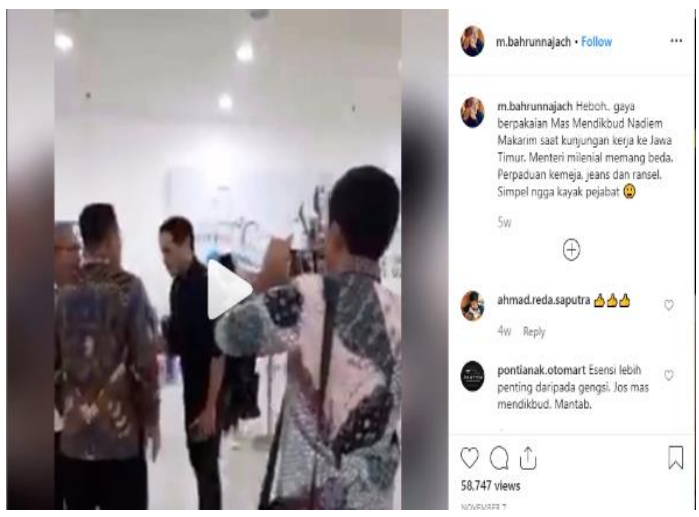

Gambar 1. Rekam layar dari akun Instagram m. bachrunnajach

Komentar yang menyebutkan bahwa perpaduan kemeja, jeans, dan ransel merupakan pakaian yang simpel dan tidak seperti pejabat menyiratkan pemikiran pemilik akun yang telah terinternalisasi oleh gagasan tentang kode-kode fashion yang mengatur pakaian pejabat negara. Pakaian Nadiem tidak mencerminkan identitas pejabat Negara. Pemikiran yang telah terinternalisasi dengan gagasan tersebut membuat pemilik akun melihatnya sebagai hal yang tidak lazim. Namun demikian, pemikiran tersebut tidak membuat penulis caption dalam video di akun Instagram m. bachrunnajach merasa Nadiem melakukan hal yang tidak patut. Satu sisi ia mengakui gagasan hegemonik bahwa pilihan Nadiem tidak sesuai dengan kode-kode fashion sebagai pejabat, namun di sisi lain ia tidak melontarkan pendapat bahwa pilihan tersebut merupakan tindakan melanggar norma. la bahkan melontarkan gagasan lain bahwa pilihan berbeda tersebut terkait dengan identitas Nadiem sebagai menteri yang mewakili generasi Millenial yang simple dan berbeda.
Bukan sekali itu saja pilihan busana Nadiem Makarim menjadi pembicaraan masyarakat luas. Busana Nadiem kembali menjadi sorotan berbagai media dan menjadi bahan perdebatan warganet saat ia menghadiri acara pelantikan Rektor Universitas Indonesia pada tanggal 4 Desember 2019. Nadiem mengenakan kemeja tenun dengan lengan baju yang digulung, dan dipadu dengan celana jeans dan sepatu loafers berbahan suede (Muhyiddin, 2019).

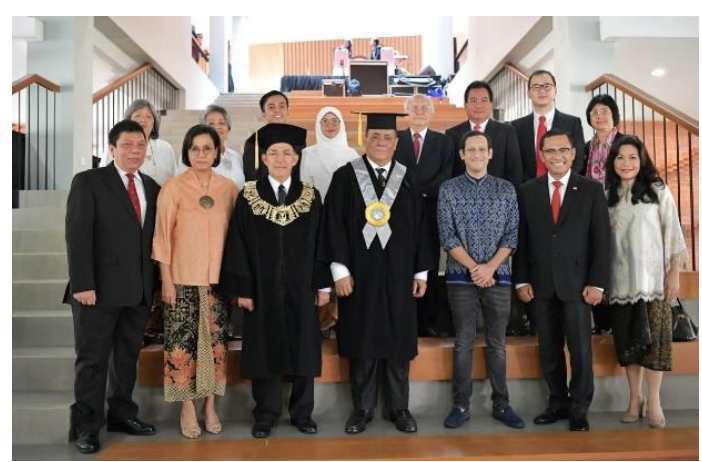

Gambar.2. Mendikbud Nadiem berfoto bersama rektor UI terpilih Prof Ari Kuncoro dan sejumlah pejabat UI (ist/humasdikbud)

(Sumber: Kurnia, 2019)

Dalam foto pada Gambar 2 terlihat pakaian yang dikenakan Nadiem berbeda dengan pejabat negara dan pejabat universitas yang hadir pada saat itu. Pakaian yang dikenakan para pejabat pria yang lain adalah pakaian yang dalam kode fashion di Indonesia disebut sebagai pakaian sipil lengkap, yaitu setelan jas berwarna hitam, kemeja putih, dasi, dan sepatu. Pakaian sipil lengkap ini biasanya dikenakan saat acara-acara kenegaraan atau acaraacara resmi. Acara pelantikan rektor sebuah universitas negeri dapat

Jurnal IImu Sosial dan Humaniora | 104 
dikategorikan sebagai sebuah acara resmi, sehingga para pejabat universitas hadir dengan pakaian sipil lengkap. Nadiem bukan hanya tidak mengenakan pakaian yang sesuai dengan kode tersebut, la justru memilih untuk mengenakan celana jeans ketat dengan warna hitam pudar yang dapat dikatakan berkebalikan dengan gambaran keformalan yang umum di masyarakat.

Beberapa artikel media daring membahas pendapat masyarakat tentang pilihan busana Nadiem di acara tersebut. Salah satu artikel tersebut adalah Republika.co.id yang mengunggah artikel berjudul Cara Nadiem Berpakaian Saat Pelantikan Rektor UI Dikritik (Muhyiddin, 2019). Dalam artikel tersebut terdapat kutipan pandangan dari wakil ketua umum sebuah partai politik di Indonesia yang pada intinya menyatakan bahwa Nadiem dengan pilhan busananya tersebut menunjukkan sikap tidak menghargai lembaga, dan tidak menunjukkan keteladanan. la menyebutkan pula bahwa bidang pendidikan tidak sama dengan ekonomi. "Di dalam pendidikan tidak sama dengan bidang ekonomi. Bidang ekonomi, menteri itu mau pakai jeans, mau pakai sandal jepit tidak apa-apa. Tapi di dalam pendidikan ada keteladanan "( dalam Muhyiddin, 2019). Pendapat tersebut di atas menunjukkan hegemoni kode-kode busana yang mengaitkan pilihan busana dengan keteladanan dan dianggap mencerminkan sebuah sikap tidak menghargai. Hegemoni tersebut berusaha dilestarikan melalui aparatusaparatus, yang salah satunya adalah tokoh masyarakat seperti yang ditunjukkan dalam artikel tersebut.
Busana, seperti produk budaya lainnya, sejatinya juga merupakan arena pertarungan, arena kontestasi untuk merebut dan mempertahankan dominasi, serta mengupayakan resistensi dan negosiasi.

"Clothing is more than mere bodily covering for protection. It is a sign system that is interconnected with the other sign systems of society through which we can send out messagesabout our attitudes, our social status, our political beliefs, etc" (Danesi, 2004).

Sebagai seorang pejabat publik yang sosoknya selalu menjadi menjadi sasaran tatapan mata masyarakat, Nadiem memilih untuk mengenakan busana yang melanggar kode-kode fashion. Mata masyarakat yang melihat segera akan menyimpulkannya sebagai upaya pembangkangan, upaya resistensi pada kode-kode yang diyakini secara luas. Pilihan Nadiem tersebut terlihat memiliki kesesuaian dengan isi pidato yang disampaikannya di acara tersebut. Dalam pidatonya, Nadiem menyampaikan tentang upaya melahirkan SDM yang unggul sebagai prioritas Kemendikbud dan perlunya kemerdekaan bagi lembaga perguruan tinggi, dosen, dan pendidik dari berbagai macam regulasi dan birokrasi, dan kemerdekaan bagi mahasiswa belajar sesuai kemauan, kemampuan, dan minat mereka (dalam Chaterine, 2019).

Nadiem seolah mengirim pesan tentang kemerdekaan memilih dan keinginan untuk mendapatkan ruangruang bagi pemikiran personal. Ruangruang bagi pemikiran pribadi dan individual menjadi penting saat ini, dalam kondisi masyarakat yang telah banyak 
mengalami perubahan, terutama dengan semakin akrabnya teknologi media daring yang memberi fasilitas dan keleluasaan pada masing-masing individu untuk mengungkapkan berbagai hal yang bersifat individual dan personal.

Namun, bila dicermati lebih jauh lagi, akan terlihat bahwa tidak semua bagian dari pakaian yang dipilih Nadiem betul-betul bertolak belakang dengan kode-kode fashion yang dianggap sesuai untuk konteks peristiwa dan identitasnya sebagai pejabat publik. Pada saat kunjungan kerja di Pasuruan, Nadiem mengenakan celana jeans dan tas ransel yang dianggap tidak mencerminkan identitasnya sebagai pejabat negara dan konteks aktivitas kerja yang sedang dilakukannya, namun ia masih mengenakan kemeja yang masih dapat diterima oleh masyarakat umum untuk dikenakan di acara-acara resmi. Pada saat Nadiem menghadiri acara pelantikan Rektor Universitas Indonesia, ia mengenakan jeans dan sepatu loafers tanpa kaos kaki yang dibaca oleh masyarakat umum sebagai pakaian santai, namun ia memadukannya dengan kemeja tenun yang masih dianggap cukup sesuai untuk dikenakan saat menghadiri acara resmi, walaupun ia menggulung lengan kemejanya yang kembali diasosiasikan dengan sikap yang santai dan kurang formal. Dalam beberapa sisi dia menolak kode-kode fashion yang berlaku, namun di sisi-sisi yang lain, ia mematuhinya.

Hegemoni dicapai dengan

konsensus. Untuk mencapai tahap tersebut melewati proses negosiasi antara kelompok yang dominan dengan kelompok-kelompok subordinasi. Melalui pilihan berbusananya, Nadiem melakukan negosiasi terhadap hegemoni kode-kode fashion yang dominan, namun juga berkompromi untuk menerima sebagian dari gagasangagasan hegemonik yang dominan di masyarakat.

Negosiasi terhadap kode-kode fashion yang dominan kerap kali ditunjukkan oleh Presiden Joko Widodo dalam beberapa kesempatan. Salah satunya adalah saat Presiden Jokowi yang saat itu sedang berlaga di kontestasi pemilihan presiden. la dan Cawapres Ma'ruf Amin dalam foto di kertas suara Pilpres 2019 mengenakan kemeja putih, sementara pasangan calon Prabowo-Sandi mengenakan jas lengkap dengan kemeja putih di dalamnya (CNN Indonesia, 2019). Kertas suara untuk pemilihan calon presiden dan wakil presiden dianggap mewakili sebuah kegiatan resmi kenegaraan, maka masyarakat pada umumnya akan melihat bahwa sewajarnya pakaian yang dikenakan adalah pakaian sipil lengkap, seperti yang diutarakan oleh Koordinator Juru Bicara Badan Pemenangan Nasional (BPN) Prabowo Subianto Sandiaga Uno, Dahnil Anzar Simanjunak, yang juga mengaitkannya dengan Peraturan Pemerintah nomor 71 tahun 2018 tentang Tata Cara Pakaian pada Acara Kenegaraan dan Acara (CNN Indonesia, 2019). Dahnil Anzar Simanjuntak menulis dalam media sosial Twitter bahwa Pemilu adalah acara kenegaraan. Prabowo Subianto menurutnya menghormati PP yang ditandangatangani Jokowi itu (dalam CNN Indonesia, 2019). "Di mana laki-laki diwajibkan menggunakan pakaian sipil nasional, jas hitam dengan kemeja putih di dalamnya. Maka Prabowo mengenakan jas," (dalam CNN Indonesia, 2019).

Jurnal IImu Sosial dan Humaniora| 106 


\section{Menanggapi perdebatan} tersebut, Jokowi menyampaikan bahwa salah satu alasan pemilihan baju putih adalah karena harga pakaian tersebut lebih murah jika dibandingkan dengan harga setelan jas. "Jas itu pakaian orang Eropa, orang Indonesia cukup baju murah, baju putih seperti yang saya pakai”, ( dalam CNN Indonesia, 2019). Jokowi menyebutkan bahwa jas adalah pakaian Eropa, dan dia, beserta orang Indonesia lain lebih cocok mengenakan kemeja. Jokowi melakukan negosiasi dengan menyandingkan jas yang disebutnya dengan budaya Eropa dengan kemeja yang walaupun telah sangat akrab sebagai busana di masyarakat, namun sesungguhnya juga merupakan pengaruh dari budaya asing pula.

Terlepas dari pertanyaanpertanyaan tersebut, sesungguhnya dalam negosiasi itu Jokowi dan timnya sedang berusaha membangun citra dan identitas mereka. Lihat saja ajakan Jokowi berikut, pada saat berkampanye di Taman Bukit Gelanggang, Riau terkait kemeja putih ini. Jokowi mengajak pendukungnya untuk datang ke TPS saat pemilihan umum dengan mengenakan kemeja putih. "Karena yang mau dicoblos nanti bajunya putih, karena Kita adalah putih, putih adalah Kita," ujarnya ( dalam CNN Indonesia, 2019). Terdapat agenda-agenda politik di balik negosiasi pada hegemoni kode-kode fashion yang dilakukan Jokowi dan timnya. Untuk menarik massa pemilih, kemeja putih dicitrakan dikaitkan dengan sikap sederhana, apa adanya, tangkas, dan siap untuk bekerja keras. Jokowi dan timnya mencoba melepaskan diri dari hegemoni lama, namun mereka turut ambil bagian sebagai apparatus yang menyebarkan hegemoni baru dengan menanamkan makna-makna tertentu pada produk-produk fashion.

Negosiasi atas hegemoni kodekode fashion yang dilakukan pejabatpejabat publik di atas mendatangkan berbagai komentar dari masyarakat, terutama warganet. Salah satu berita terkait pilihan busana Nadiem yang cukup banyak mengundang perhatian warganet adalah artikel berjudul "Busana 'Santai' Nadiem di Pelantikan Rektor Dikritk, Ini Kata Kemendikbud" (Rizqo, 2019), yang diunggah oleh situs berita daring detikNews pada tanggal 6 Desember 2019. Komentar-komentar yang terkait dengan pilihan busana Nadiem terdiri atas komentar yang bernada menentang, mendukung pilihan busana Nadiem, tidak menentang atau mendukung sepenuhnya, dan komentarkomentar yang memprotes warganet yang berdebat tentang pakaian yang mereka anggap bukan persoalan penting. Komentar-komentar tersebut tidak dapat disajikan secara keseluruhan, namun akan dipilih beberapa yang mewakili.

Cukup banyak komentar yang menunjukkan sikap mendukung pilihan busana Nadiem. Komentar-komentar tersebut di antaranya adalah sebagai berikut.

"Pekaian yang menipu, pejabat bertampang dan penampilan keren serta omongnya hebat sudah banyak yang ketangkap KPK, yang penting jujur dan berintegritas. Tampil hebat, tahu2 penghianat negara, malu sama dunia, jujur dan apa adanya itu lebih baik." (Ajik Bagus)

Jurnal IImu Sosial dan Humaniora | 107 
"Jangan menilai dari sampulnya, dunia pendidikan tidak butuh kemasannya, isinya yang kita butuhkan. Anggota DPR pakai jas keren namun dicokok sama KPK." (Masly)

"Lebih baik daripada pakai jas hasil nepotisme." (Toko Lima)

"Yang kritik Itu mencerminkan bahwa itulah orang banyakkan melihat dari luar saja, mudah tertipu. Pakai Jas, kalau koruptor buat apa? Pakai pakaian Gamis tapi bejad buat apa? Yang penting kerjanya nyata, hasilnya nyata. Kapan Indonesia akan jadi negara Super Power, kalau mentalnya mental cengeng, manja dan mau kelihatannya bagus tapi bobrok di dalam. Pakaian (jas, jubah, kemeja, sorban) bukan yang membuat orang jadi benar dan baik, tapi Perbuatan, ucapan, dan moral". (Pan's Dj)

Komentar-komentar tersebut di atas mewakili komentar yang mencoba melakukan negosiasi dengan cara membongkar konstruksi yang ditanamkan dalam kode-kode fashion, yaitu bahwa kepatuhan pada kode fashion mencerminkan integritas, kepatuhan pada hukum dan normanorma sosial, dan kinerja yang baik. Mereka yang berpakaian sesuai kodekode fashion yang berterima belum tentu tidak melakukan tindakan melanggar hukum, seperti korupsi dan nepotisme. Dengan demikian, sebaliknya, ketidaktaatan pada kode-kode fashion yang dominan tidak serta merta dapat dianggap mencerminkan kecenderungan tidak taat pada hukum dan norma-norma sosial, dan tidak pula dapat dijadikan sebagai landasan dugaan pada kinerja yang buruk.

Seperti komentar-komentar di atas, komentar di bawah ini juga merupakan upaya melakukan negosiasi.

"Emang kenapa pakaiannya Pak Mentri? Keren kok. Daripada berpakain resmi tapi kerja korupsi aja buat apa. Terus gayamu Pak Menteri. Yang penting tunjukan kinerja dan program-programmu, agar pendidikan di Indonesia bisa lebih hebat, dan BANTAI para koruptor di Departemen di bawah naungan Anda." (Martin Juliando)

"Super cocok, fokus ke substansi pendidikan, abaikan hal yang tidak substansi. Maju terus sukses pendidikan Indonesia." (Sularwo Yogya)

"Zaman now seharusnya universitas melepaskan diri dari gaya atistrokat model jaman baheula. Pakai jubahjubah dan toga-toga yg sebenarnya dilihat menggelikan ya. Yang penting kualitas pendidikan bisa maju dan bersaing dg negara-negara maju di dunia, bukan jamannya jubah-jubahan yg disakralkan." (Zoro09)

"Jangan menilai dari sampulnya, dunia pendidikan tidak butuh kemasannya, isinya yang kita butuhkan, anggota DPR pakai jas keren namun dicokok ama KPK." (Masly)

Komentar-komentar di atas menggambarkan upaya untuk 
melakukan negosiasi pada kode-kode fashion dengan menegosiasi nilai penting dari pakaian dengan cara memposisikannya berhadap-hadapan dengan hal lain yang penting, yaitu berbagai permasalahan terkait pendidikan di Indonesia, bidang kerja Nadiem sebagai menteri.

Komentar-komentar berikut menunjukkan persetujuan pada kodekode fashion, namun sekaligus juga persetujuan pada upaya negosiasi.

"Buat saya, ora opoo, Pak, asal kinerja dan inovasi bagus.. sekarang jamannya kerja aja Pak. Pak kyai aja pake sarung ayoo ajaa." (Aku Fhiko)

"Pernah liat Bill Gates, orang orang besar di dunia gayanya? Mereka semua santai saja yang penting OTAK untuk membuat perubahan. Steve Jobs bahkan di kantornya tanpa alas kaki. Banyak orang menutupi kekurangan dengan Pakaian Necis dan Formal. Tapi yah mungkin baiknya untuk acara resmi lebih formal agar tidak terlalu kontras." (Prince Universe)

Dua pendapat tersebut menyiratkan makna bahwa sebetulnya pakaian santai dan sarung merupakan pilihan pakaian yang tidak sesuai untuk situasi kerja. Pendapat kedua (dari Prince Universe) juga menyebutkan perlunya sedikit menyesuaikan terutama dalam acara formal. Kedua komentar tersebut menyiratkan dua busana yang tidak sesuai untuk situasi kerja masih bisa diterima dengan syarat, yaitu: harus menunjukkan kinerja yang baik dengan hasil kinerja yang memuaskan.
Pendapat yang menujukkan persetujuan pada kode-kode fashion yang hegemonik, namun sekaligus juga menunjukkan upaya melakukan negosiasi terlihat pula dalam beberapa komentar berikut.

"Selama masih sopan...nggak apaapa...kecuali kalau pakai singlet celana pendek dan sandal jepit... yang penting prestasi kerja banyak yang pakai jas berdasi tapi korupsi." (Ag s)

"Bagiku gak masalah, walau pejabat negara. Santai aja bro, yang penting masih sopan." (Max77)

"Bagusan apa adanya asal rapi dan daripada pake jas puluhan juta biar dibilang yang mulia yang terhormat." (KepZ)

"Bebas tapi sopan. Santuy. dari pada berdasi korupsi." (Detikteguh)

"Yang penting pakaian rapi dan bisa kerja." (Asang Irama)

Bila komentar-komentar sebelumnya menunjukkan sebagian persetujuan dengan memberikan syarat yaitu kinerja yang baik, maka komentar-komentar di atas menunjukkan sebagian persetujuan dalam pilihan busana. Ketidaksesuaian dengan kode-kode fashion yang dominan masih bisa diterima dalam batasan-batasan, yaitu masih dalam batasan-batasan kesopanan, yang juga merupakan hasil konsensus bersama

Busana, seperti produk budaya lainnya, sejatinya juga merupakan arena pertarungan, kontestasi untuk merebut, mempertahankan dominasi, dan mengupayakan resistensi serta 
negosiasi. Komentar-komentar yang telah disajikan sebelumnya menunjukkan upaya negosiasi, namun di waktu yang sama menunjukan pola persetujuan pada kode-kode fashion yang telah dianggap sebagai kelaziman. Tidak hanya upaya-upaya melakukan negosiasi, muncul pula komentarkomentar yang menunjukkan hegemoni kode-kode fashion dan turut andil dalam mempertahankan hegemoni tersebut. Komentar-komentar tersebut di antaranya sebagai berikut.

"Ada aja komentar2 konyol. Yang namanya Menteri Pendidikan ya harus tahu CARA BERPAKAIAN lah. Wong di dunia pendidikan, anak2 aja diajarkan untuk tahu tempat berpenampilan kok masak menteri kita sendiri malah begitu. Even dia ga background dari pendidikan sekalipun, ya sudah amanah dia pun harus berkarakter sebagaimana orang-orang di dunia pendidikan. Ini bukan di budaya kantoran dan segala macamnya lagi. Untung2 ga pakai TShirt. Sorry for this attitude, I really disagree." (Pris)

"Sebagai pejabat negara, NM ini seharusnya bisa membedakan apakah beliau menghadiri acara formal atau non formal. Acara pelantikan adalah acara formal, dan dalam acara formal/ resmi spt itu pakaian yg dikenakan juga pakaian formal. Ini berlaku tidak hanya utk yang dilantik saja, tapi juga bagi para undangan. Beliau seharusnya bisa menghormati. Dan yang harus beliau ingat, beliau tidak lagi bekerja di perusahaan swasta yang membebaskan cara berpakaian pekerjanya (dari karyawan biasa sampai CEO). Tapi beliau sekarang termasuk Aparat Sipil Negara, yaitu sebagai Pejabat Negara. Beliau harusnya juga memberi contoh dan menjadi teladan. Memang banyak anak muda cerdas saat ini, tapi banyak juga dari mereka yang tidak memahami etika berbusana sesuai tempat dan waktu." (Ekova Avianti)

"Jangan sampai karena kepinteran otaknya terus melupakan etika budaya orang timur, akan lebih baik bila menghargai orang lain, kalau sampai meninggalkan etika dan budaya adat ketimuran saya sangat menyayangkan." (Om Pakto Pakto)

"Milenial mana ada sopan santun sih.... kan sudah banyak bukti." (JohnLove)

"Berpakaian kan ada aturannya, itu kan kata menteri agama juga." (A Halim)

"Apapun alasannya, jelas kelihatan pribadi yang tidak bisa menempatkan diri. Ini jelas berkaitan dengan etika. Dia mungkin meniru gaya profesor Amerika, yang santai, tapi profesor Amerika itu bisa memilah milah mana yg bisa dengan pakaian santai dan formal. Jadi ingat penyanyi tenar kita diundang ke Grammy Award ke Amerika dengan pakaian jeans yg sobek2, akhirnya dinobatkan sebagai tamu berpakaian paling buruk. Malu

Jurnal IImu Sosial dan Humaniora | 110 
nya...Setelah itu dia selalu berpakaian formal setiap ada undangan."(Pandan08)

"Ingin tampil beda, sederhana,biar viral, tapi keliru, tidak bisa menempatkan sesuatu pada tempatnya. Santai boleh, tapi muruah /wibawa sebagai sosok pemimpin mesti tetap dijaga." (Gendhenk).

Komentar-komentar di atas menunjukkan ketidaksetujuan pada pilihan busana Nadiem Makarim. Penulis-penulis komentar memiliki keyakinan bahwa pilihan busana berkaitan erat dengan sikap pada pihak lain, status/ jabatan, kewibawaan, intektualitas, tingkat pendidikan, etika, sopan-santun, aturan agama, dan budaya ketimuran. Gagasan-gagasan bahwa pada pakaian melekat kualitaskualitas tersebut di atas telah distrukturkan di masyarakat dan tertanam secara hegemonik. Masyarakat luas mempercayai bahwa peningkatan level jabatan, pendidikan, dan intelektualitas seharusnya sejalan dengan peningkatan pemahaman dan kepatuhannya pada kode-kode fashion. Bila seseorang melakukan pelanggaran pada kode-kode fashion berarti ia telah melakukan pelanggaran pada normanorma sosial dan norma-norma adat. Komentar-komentar tersebut menunjukkan hegemoni yang telah bekerja dalam melihat suatu kenyataan. Kemudian, secara tidak disadari, sebetulnya komentar-komentar tersebut turut ambil bagian dalam mempertahankannya.
Upaya

mempertahankan hegemoni pada umumnya dilakukan melalui institusi-institusi masyarakat, seperti keluarga, pendidikan, agama, media massa, budaya popular, orangorang yang bergerak di dunia fashion, instansi pemerintah dan swasta, dan lain-lain. Dalam peristiwa pilihan busana Nadiem Makarim, muncul pula pendapat dari seorang fashion designer yang turut beperan mempertahankan hegemoni kode-kode fashion. Berikut rangkuman dari komentar Musa Widyatmojo, seorang fashion designer seperti yang dikutip dari situs berita online Kompas.com, dengan judul "Kata Desainer soal Gaya Berpakaian Kasual ala Nadiem Makarim."(Tashandra \& Kumaladewi, 2019).

"Secara fashion, yang ingin disampaikan Nadiem adalah kesan muda, kasual, bersahaja, dan tidak protokoler. Namun suatu pilihan yang di luar kebiasaan dikhawatirkan menimbulkan satu reaksi dari masyarakat, baik reaksi positif maupun negatif. Selalu ada resiko di balik suatu profesi atau jabatan, termasuk untuk mengikuti tata aturan berbusana. Posisi Nadiem saat ini tidak lagi sebagai pimpinan perusahaan, tetapi seorang pejabat negara yang menjadi contoh seluruh masyarakat. Apalagi di era 4.0 ini, dominasi media sosial sangat besar sehingga penampilan atau visual seorang pejabat negara akan mudah disebarkan lewat berbagai platform. Visualisasi diri melalui busana juga menjadi catatan yang amat sangat penting, sebab dari situ dapat dilihat apakah seseorang pandai beradaptasi, buta fashion, atau sadar

Jurnal IImu Sosial dan Humaniora | 111 
fashion. Gaya berpakaian sebetulnya menjadi bagian dari diplomasi (fashion diplomacy) yang penting untuk diperhatikan, tidak terkecuali bagi para pejabat negara. Selama dikenakan secara pas dan pada waktu yang tepat, seseorang sebenarnya tetap bisa bereksplorasi dengan gaya berbusana sesuai dengan kepribadiannya." (dalam Tashandra et al., 2019)

Pendapat dari fashion designer tersebut di atas mencoba kembali memperkuat hegemoni fashion dengan menanamkan gagasan bahwa kode-kode fashion perlu dipatuhi demi menjaga kestabilan, dan sebagai pejabat publik Nadiem perlu memperhatikan kode-kode fashion sebagai bagian dari bentuk diplomasi. Pilihan untuk menunjukkan kepribadian dapat dilakukan, asalkan dalam koridor, sesuai konsensus yang telah disepakati dalam kode-kode fashion tersebut. Melalui pendapat di atas, fashion designer tersebut menjadi bagian dari apparatus yang turut mempertahankan hegemoni.

"Budaya adalah tempat pergumulan ideologis, sebuah ranah 'inkorporasi' dan 'resistensi', salah satu tempat di mana hegemoni dimenangkan atau kalah" (Stuart Hall dalam Storey et al., 2007). Komentar dari akun Instagram m.bahrunnajach, beberapa artikel-artikel pemberitaan, dan komentar-komentar dari warganet di berbagai media daring, memperlihatkan pergumulan ideologis dalam hegemoni kode-kode fashion. Terlihat upaya-upaya mempertahankan gagasan hegemonik yang lama, upayaupaya negosiasi, kompromi, dan bahkan upaya-upaya untuk melakukan transformasi pada kode-kode fashion yang selama ini berlaku.

\section{Transformasi Kode-Kode Fashion yang Dominan}

Pasca peristiwa konferensi pers saat Presiden Jokowi mengenakan jaket bomber ditayangkan, model jaket bomber berwarna hijau army banyak dicari dan menjadi populer di masyarakat. Masyarakat, terutama anakanak muda, berusaha mencari informasi terkait jenis, merk, dan harga jaket tersebut. Hal ini tidak mengherankan karena manusia memiliki kecenderungan secara alamiah untuk membandingkan perilakunya dengan orang-orang yang mereka anggap penting (anak pada orang tua, seseorang yang menempati posisi lebih rendah kepada mereka yang memiliki posisi lebih tinggi dan sebagainya) sebagai upaya untuk menirukannya (Kant dalam Meinhold et al., 2014). Apalagi bila fashion yang digunakan oleh orang-orang yang mereka anggap penting tersebut sesuai dengan seleranya, yang sebetulnya telah distrukturkan oleh berbagai gagasangagasan hegemonik di masyarakat

Jaket bomber Jokowi malam itu diduga produk perusahaan busana Zara (Stefanie, 2016).Jaket tersebut pun kemudian secara cepat terjual di tiga butik milik Zara yang berada di Plaza Indonesia, Grand Indonesia, dan Pondok Indah Mall (Stefanie, 2016). Bahkan saham PT Mitra Adiperkasa Tbk, perusahaan yang memasarkan produk Zara di Indonesia, melonjak 250 poin beberapa hari setelah unjuk rasa yang menjadi topik konferensi pers Presiden Jokowi (Stefanie, 2016). Setelah munculnya trend tersebut banyak jaket- 
jaket dengan model serupa, produk dari berbagai produsen beredar di pasaran, yang tentunya untuk memanfaatkan moment dan meraih keuntungan. Dari peristiwa tersebut, terlihat bahwa viralnya gaya busana Jokowi yang dianggap berbeda dengan kode-kode fashion yang dianggap cocok dikenakan seorang pejabat negara di depan publik, ternyata membawa keuntungan untuk produsen-produsen pakaian.

Industri mode, dan berbagai perlengkapan busana, mulai dari bahan baku hingga perakitan dan retailretailnya tentu membutuhkan pasar bagi produk-produknya. Hegemoni budaya tentang kode-kode fashion yang kuat namun sekaligus juga fleksibel dan adaptif terhadap perubahan akan membuat masyarakat berusaha mematuhinya dan mengejar mengikutinya dengan terus membeli pakaian-pakaian beserta segala perlengkapannya. Kondisi tersebut akan membuka pasar yang tidak pernah mati bagi industri-industri terkait fashion. Proses negosiasi yang kemudian disikapi dengan penyesuaian-penyesuaian pun akan melahirkan konsensus baru, hegemoni baru, konsep-konsep baru yang disematkan pada komoditas, yang akan mendatangkan keuntungan lagi untuk mereka, kelompok-kelompok penguasa sesungguhnya, para pengusaha pemilik modal.

Sebagian besar keberhasilan hegemoni budaya disebabkan karena sifatnya yang fleksibel, responsif pada perubahan kondisi dan adaptif (O Connor dalam Ibrahim et al., 1997). Dalam dunia dengan tatanan hegemonik memiliki tingkat fleksibilitas dan kapasitas adaptif inilah cengkeraman gurita budaya dan ideologi kapitalisme justu makin menguat
(O Connor dalam Ibrahim et al., 1997). Pada negosiasi-negosiasi yang diperlihatkan oleh pilihan berbusana para pejabat publik dan berbagai opini-opini dari masyarakat yang muncul di berbagai media terlihat upaya untuk melahirkan persetujuan-persetujuan baru.

Fleksibilitas dan mengaburnya batas-batas yang sebelumnya terasa kaku serta mengikat sebetulnya merupakan hal yang tak asing sejak munculnya teknologi internet. Teknologi ini telah memungkinkan aktivitas berkelana di dunia maya, yang membuat jarak, batas-batas ruang serta waktu, menghilang. Semuanya menjadi lebih lentur, lebih fleksibel. Fleksibilitas ini kemudian juga menjadi salah satu ciri dari sistem produksi dan konsumsi di era Post-Fordism. Transformasi dalam kapitalisme, dari Fordism ke PostFordism, berpengaruh tak hanya pada proses produksi, tetapi juga pada regulasi sosial, konstelasi politik, dan sistem budaya (Fisher, 2010) Transformasi tersebut tak dapat dilepaskan dari perubahan di masyarakat yang diakibatkan oleh berkembangnya teknologi media. Masyarakat yang terhubung satu sama lain dalam jaringan internet, telah mengarahkan dunia bisnis dan perekonomian pada desentralisasi. Minimnya sentralisasi dan berkurangnya intervensi regulasi eksternal mengakibatkan proses produksi dan situasi pasar menjadi sangat cepat berubah. Dalam kondisi yang demikan fluktuatif, menurut wacana-wacana TIK dan media digital, fleksibilitas sangat dibutuhkan untuk mampu bertahan.

$$
\text { Gagasan-gagasan }
$$

tentang mengaburnya batas-batas dan gagasangagasan tentang kelenturan dan fleksibilitas merambah pula pada dunia 
fashion. Masyarakat, terutama kaum muda, tak lagi melihat perlunya batasbatas yang kaku bagi kode-kode fashion untuk menjalankan berbagai aktivitas. Masyarakat makin menghendaki pengakuan dan ruang-ruang yang terbuka untuk berbagai kreatifitas dan aspirasi yang bersifat individual. Dari sisi industri pun, agar dapat bertahan dalam perubahan, berbagai bisnis di dunia fashion dituntut untuk dapat beradaptasi, lentur dalam menerima gagasangagasan fleksibilitas itu. Mereka harus mampu mengakomodir upaya negosiasi, memberi ruang-ruang yang menjanjikan untuk kreatifitas yang bersifat personal agar dapat menarik perhatian konsumen, namun sekaligus tetap menggenggam masyarakat dalam kuasanya, serta tentunya memperoleh keuntungankeuntungan yang diharapkan.

Jokowi menyebutkan jaket yang dikenakannya pada malam konferensi pers terkait peristiwa demonstrasi besar di Jakarta, bukanlah miliknya. Jaket itu diakuinya milik putra bungsunya, seorang usia yang tentu bergaya muda. Jaket tersebut menarik perhatian masyarakat, terutama generasi muda karena menampilkan gaya anak muda yang kasual dan terkesan tidak formal, tidak selazimnya busana yang dikenakan oleh seorang presidan dalam suatu konferensi pers. Gaya Nadiem Makarim yang sering diberi julukan sebagai menteri millennial banyak disebut oleh media-media daring seperti 'anak kuliahan'. Gaya 'Kekinian', seperti ‘anak kuliahan', 'millenial' merupakan ungkapan-ungkapan yang biasanya merujuk pada gaya anak muda.

Menjadi muda tampaknya telah menjadi hal yang penting saat ini, dan bila diwujudkan dalam gaya fashion, ungkapan-ungkapan tersebut dimaknai sebagai gaya yang kasual, tidak protokoler, memberi kesan enerjik, simple, dan modis. Gaya tersebut memperlihatkan pula pilihan yang lebih bersifat personal, tak sepenuhnya mengikuti aturan-aturan baku fashion yang lazim, walaupun memang tak melenceng terlalu jauh darinya. Gaya fashion yang disebut sebagai gaya millennial dan kekinian dipadukan dengan kode-kode fashion yang ada sebelumnya, menjadi kode-kode fashion yang baru. Kode-kode fashion untuk mengikuti aturan-aturan berbusana yang berlaku namun lebih fleksibel untuk menujukkan selera personal, dan menampilkan kepribadian yang muda dan bergaya.

Masyarakat seolah diberikan keleluasaan untuk memilih produkproduk yang sesuai dengan keinginan mereka dan tidak melulu harus mengikuti kode-kode fashion yang selama ini diyakini. Kebebasan itu berada dalam batasan-batasan pilihan produk yang ditawarkan oleh produsen. Pilihan-pilihan yang dibuat oleh masyarakat diarahkan oleh pemikiran-pemikiran tentang pakaian dengan imaji yang dilekatkan padanya. Ketika gagasan hegemonik telah merasuk dan membalsem kesadaran masyarakat, mereka akan percaya bahwa orang-orang yang mengenakan komoditas-komoditas itu benar-benar orang-orang yang memiliki kualitas dan kepribadian seperti gambaran yang disematkan pada produk-produk fashion tersebut. Dalam kebebasan tersebut sesungguhnya mereka diposisikan untuk terus membeli berbagai produk yang dianggap terhubung dengan identitas yang ingin ditampilkan. Masyarakat, terutama kaum 
muda masa kini percaya bahwa mereka tak lagi berada dalam batasan-batasan yang kaku dari kode-kode fashion yang berlaku, namun sesungguhnya mereka tidak lebih hanyalah berpindah, lepas dari batasan kuasa gagasan hegemoni yang lama dan masuk dalam kuasa hegemoni yang baru.

\section{SIMPULAN DAN SARAN}

Pakaian dan berbagai perlengkapannya merupakan salah satu produk budaya yang merupakan arena kontestasi antara gagasan-gagasan yang hegemonik dan upaya resistensi serta negosiasi. Fashion statement yang dilakukan oleh Nadiem Makarim sebagai menteri Pendidikan dan Kebudayaan dan Presiden Jokowi terhubung dengan upaya sebagian anggota masyarakat dalam melakukan negosiasi pada kodekode fashion yang berlaku, namun di saat yang bersamaan juga masih menunjukkan persetujuan pada konsepkonsep yang hegemonik tersebut. Kondisi masyarakat yang saling terhubung dengan teknologi media daring telah mendukung terjadinya transformasi pada pada sistem kapitalis, menjadi sistem yang lebih memberikan penekanan pada desentralisasi, fleksibilitas, dan partisipasi individu. Transformasi tersebut terjadi pula dalam dunia fashion. Transformasi pada kodekode fashion tersebut telah menyematkan nilai hegemonik baru pada komoditi fashion, sehingga terus menerus memunculkan kebutuhan mengkonsumsinya, dan tidak pelak lagi akan membuka pasar yang tidak pernah mati bagi bisnis dan industri-industri pendukungnya. Pada akhirnya hegemoni budaya pada produk fashion bekerja untuk penguasa yang sesungguhnya, yaitu mereka para pemilik modal.

\section{DAFTAR PUSTAKA}

Chaterine, R. N. (2019). Di Pelantikan Rektor UI, Nadiem Bicara Kemerdekaan Belajar-Dosen Penggerak. News.Detik.Com. https://news.detik.com/berita/d4809275/di-pelantikan-rektor-uinadiem-bicara-kemerdekaanbelajar-dosen-penggerak

CNN Indonesia. (2019). Jokowi Sebut Jas Pakaian Eropa, BPN Singgung PP Pakaian Resmi. Www.Cnnindonesia.Com. https://www.cnnindonesia.com/nasi onal/20190327191140-32-

381260/jokowi-sebut-jas-pakaianeropa-bpn-singgung-pp-pakaianresmi

Danesi, M. (2004). Popular Culture: Messages, Sign, and Meanings: $A$ Basic Textbook in Semiotics and Comunication Theory (Third Edit). Canadian Scholars' Press Inc.

Faruk. (2017). Pengantar Sosiologi Sastra dari Stukrutalisme Genetik sampai Post-Modernisme. Pustaka Pelajar.

Fisher, E. (2010). Media and New Capitalism in The Digital Age. PALGRAVE MACMILLAN.

Ibrahim, I. S., Malik, D. D., Rakhmat, J., \& Latif, Yudi. (1997). Hegemoni Budaya (I. S. I. Ibrahim \& D. D. Malik (eds.)). Yayasan Bentang Budaya.

Jensen, F., \& Nangoy, F. (2019). Indonesian President's Call for Calm Makes Fashion Statement. Www.Reuters.Com. https://www.reuters.com/article/usindonesia-protestsjacket/indonesian-presidents-call-

Jurnal IImu Sosial dan Humaniora | 115 
for-calm-makes-fashion-statementidUSKBN132127

Kellner, D., \& Rambatan, G. B. (2010). Budaya Media: Cultural Studies, Identitas, dan Politik antara Modern dan Postmodern ( diterjemahkan oleh Galih Bondan Rambatan). Jalasutra.

Kurnia, I. (2019). Hadiri Pelantikan Rektor UI, Nadiem Ingatkan Peran PT dalam Menciptakan SDM Unggul. Menara62.Com. https://menara62.com/hadiripelantikan-rektor-ui-nadiemingatkan-peran-pt-dalammenciptakan-sdm-unggul/

Meinhold, R., Irons, J., \& Knowledge Unlatched - KU Select: B. (2014). A Critical Inquiry into Fashion. In Fashion Myths (pp. 9-36). Transcrpit Verlag. https://doi.org/10.14361/transcript.9 783839424377.9

Muhyiddin. (2019). Cara Nadiem Berpakaian Saat Pelantikan Rektor UI Dikritik.

Nasional.Republika.Co.Id.

https://nasional.republika.co.id/berit a/q2ejgu377/cara-nadiem-

berpakaian-saat-pelantikan-rektorui-dikritik

Rizqo, K. A. (2019). Busana "Santai" Nadiem di Pelantikan Rektor Dikritik, Ini Kata Kemendikbud. News.Detik.Com. https://news.detik.com/berita/d4812661/busana-santai-nadiem-dipelantikan-rektor-dikritik-ini-katakemendikbud

Stefanie, C. (2016). Pemilik Asli Jaket Bomber yang Dikenakan Jokowi. Www.Cnnindonesia.Com. https://www.cnnindonesia.com/gay a-hidup/20161108144414-277- 171186/pemilik-asli-jaket-bomberyang-dikenakan-jokowi

Storey, J., Rahmawati, L., \& Adlin, A. (2007). Pengantar Komprehensif Teori dan Metode Cultural Studies dan Kajian Budaya Pop ( diterjemahkan oleh Laily Rachmawati) (A. Adlin (ed.)). Jalasutra.

Strinati, D., \& Muchid, A. (2010). Popular Culture: Pengantar Menuju Teori Budaya Populer (diterjemahkan oleh Abdul Muchid). Ar Ruzz Media.

Tashandra, N., \& Kumaladewi, B. (2019). Kata Desainer Soal Gaya Berpakaian Kasual Ala Nadiem Makarim. Lifestyle.Kompas.Com. https://lifestyle.kompas.com/read/2 019/12/06/092601020/katadesainer-soal-gaya-berpakaiankasual-ala-nadiem-makarim

Walton, D. (2008). Introducing Cultural Studies: Learning Through Practice. SAGE Publications. 